Article

\title{
Antimicrobial, Antioxidant Activities, and HPLC Determination of the Major Components of Verbena carolina (Verbenaceae) ${ }^{\dagger}$
}

\author{
Gonzalo Lara-Issasi ${ }^{1}{ }^{\circledR}$, Cecilia Salgado ${ }^{1}$, José Pedraza-Chaverri ${ }^{1}{ }^{\circledR}$, \\ Omar N. Medina-Campos ${ }^{1}$ (D) Agustín Morales ${ }^{1}$, Marco A. Águila ${ }^{1}$, Margarita Avilés ${ }^{2}$, \\ Blanca E. Rivero-Cruz ${ }^{1}$, Víctor Navarro ${ }^{3}$ (D) Ramiro Ríos-Gómez $^{4}$ and María Isabel Aguilar ${ }^{1, *}$ \\ 1 Facultad de Química, Universidad Nacional Autónoma de México, Ciudad Universitaria, México D.F. 04510, \\ Mexico; laraissasi@gmail.com (G.L.-I.); ceci_060192@hotmail.com (C.S.); pedraza@unam.mx (J.P.-C.); \\ omarnoelmedina@gmail.com (O.N.M.-C.); agusmr77@hotmail.com (A.M.); parsel85@hotmail.com (M.A.Á.); \\ catequina@hotmail.com (B.E.R.-C.) \\ 2 Jardín Etnobotánico. Centro INAH, Cuernavaca, Morelos 62440, Mexico; avilesmargarita@hotmail.com \\ 3 Laboratorio de Microbiología, Centro de Investigación Biomédica del Sur, Instituto Mexicano del Seguro \\ Social, Xochitepec, Morelos 62790, Mexico; vmnavg@yahoo.com.mx \\ 4 Unidad de Investigación en Sistemática Vegetal y Suelo, FES Zaragoza, Universidad Nacional Autónoma de \\ México, Batalla 5 de mayo y P. Elías calles s/n. Col. Ejército de Oriente, Iztapalapa 09230, Mexico; \\ riosarana44@gmail.com \\ * Correspondence: laurents@unam.mx; Tel.: +52-5556-225281 \\ + Taken in part from the MSc Thesis of G. Lara.
}

Academic Editor: Francesco Epifano

Received: 3 May 2019; Accepted: 20 May 2019; Published: 22 May 2019

\begin{abstract}
Verbena carolina L. (Verbenaceae) is used as a decoction in Mexican folk medicine with applications against digestive problems and for dermatological infections. The present work firstly reported HPLC analysis, as well as the free radical scavenging capacity of the extracts and isolated compounds. Antimicrobial analyses of these substances against the bacteria Staphylococcus aureus, Enterococcus faecalis, Escherichia coli and Salmonella typhi and the fungi Candida albicans, Trichophyton mentagrophytes and T. rubrum were also tested, as well as the acute oral toxicity in mice of aqueous extracts. Major secondary metabolites in $V$. carolina extracts were isolated by conventional phytochemical methods which consisted of three terpenoids ((1), (3) and (4)) and four phenolic compounds ((2), (4)-(6)). Their contents were determined by HPLC in six different samples from different locations. The results indicated that ursolic acid (1), hispidulin (2), verbenaline (3), hastatoside (4), verbascoside (5), hispidulin 7-O- $\beta$-D-glucuronopyranoside (6) and pectolinaringenin-7-O- $\alpha$-D-glucuronopyranoside (7) were the main constituents and ranged from 0.17 to $3.37 \mathrm{mg} / \mathrm{g}$ of dried plant, with verbascoside being the most abundant and with a significant antioxidant activity in reactive oxygen species (ROS). Hispidulin was the only active compound against T. mentagrophytes and T. rubrum. The aqueous extract showed no significant toxicity $\left(\mathrm{LD}_{50}:>5000 \mathrm{mg} / \mathrm{mL}\right)$. To our knowledge, this is the first comprehensive report of the chemical characterization of $V$. carolina and also of the activity of its constituents towards reactive oxygen species and dermatophytes, and its safety for consumption.
\end{abstract}

Keywords: Verbena carolina; antioxidant capacity; HPLC determination; medicinal plants

\section{Introduction}

Verbena carolina L. (Verbenaceae) is one of the predominant species of the Verbena genus that grows in the American continent, and is widely distributed from the southwestern region of the 
United States to Nicaragua in Central America. In Mexico, this plant is popularly known as 'verbena', 'ajenjo grande', 'hierba de San José', 'nardo de campo', 'Santa María', 'poleo negro' and 'wahichuri' (Tarahumara language). It is generally referred to as 'varvain' in English. [1,2]. Verbena has a long history of traditional efficacy in Mexico. Most of the plant, except for the roots, is used as a decoction in folk medicine with applications against diarrhea, vomit and dysentery, or as a purgative. Furthermore, the decoction of the aerial parts of $V$. carolina is used to dissolve bladder stones, as a diuretic and to treat wounds, dandruff, allergies and dermatitis [1]. This plant is one of the constituents of a skin care preparation which shows melanogenesis suppression [3]. Favari-Perozzi et al. [2] tested a possible protective effect of verbena extracts in carbon tetrachloride-induced rat liver injury, and Castro et al. [4] determined some of the chemical nutrients, toxic factors, and digestibility of V. carolina L. However, the chemical and biological analyses related to the traditional uses and safe prescription of this plant are scarce. Due to the importance of V. carolina, it was selected for a program that aims to characterize and include the Mexican medicinal flora in the Mexican Herbal Pharmacopoeia. Accordingly, the purpose of this work is to investigate the major secondary metabolites contained in the extracts of $V$. carolina L., to quantify them by HPLC, and characterize some efficacy parameters such as the free radical scavenging capacity and anti-dermatophyte activity, and also to analyze the safety of its aqueous extracts. To our knowledge, this is reported here for the first time.

\section{Results and Discussion}

\subsection{Chemical Composition}

The isolation and identification of ursolic acid (1), hispidulin (2), verbenalin (3), hastatoside (4), verbascoside (5), hispidulin 7-O- $\beta$-D-glucuronopyranoside (6) and pectolinaringenin-7-O- $\alpha$ D-glucuronopyranoside (7) from the extracts of $V$. carolina was achieved.

From the dichloromethane extract, the chromatographic fraction CDE-3 was submitted to methylation and analyzed by GC-MS. It yielded palmitic, stearic, $(Z, Z)-9,12$-octadienoic, $(Z, Z, Z)$ 9,12,15-octadecatrienoic and araquidic methyl esters. Fraction CDE-13 eluted with n-hexane-EtOAc $(5.5: 4.5 \mathrm{v} / \mathrm{v})$. After methanol recrystallization, this fraction gave ursolic acid ((1), 1.1\% yield) which has also been isolated from other Verbena species [5]. The antimicrobial activity of this compound has been reported [6].

A silica gel column chromatography was applied for the acetone extract; fraction CAE-4 provided the flavonoid hispidulin (2), which showed low antimicrobial activity against S. aureus (MIC $100 \mu \mathrm{g} / \mathrm{mL}$ ). However, in the assays with the fungi T. mentagrophytes and T. rubrum, MIC values of $12 \mu \mathrm{g} / \mathrm{mL}$ were obtained. This is important, because one of the traditional uses of the plant is to treat dandruff. Verbenalin (3) was isolated from chromatographic fraction CME-15 as colorless crystals after recrystallization. Fraction CME-20 yielded white crystals that were identified as hastatoside (4). Fraction CME-30 yielded a brownish solid, identified as verbascoside (5).

Compounds 2, 3, 4 and 5 have been isolated from other species of the Verbena genus $[5,7,8]$. Hispidulin (2) has been isolated from V. officinalis and V. citriodora [9]; this compound has demonstrated to have potent antioxidant, antifungal, anti-inflammatory, antimutagenic and anticonvulsant activities [10-13]. It has also showed a strong inhibition of lipid peroxidation in mouse liver homogenates, and has a weak scavenging activity [14]. Hispidulin also exerts anti-osteoporotic and bone resorption inhibiting effects via activation of the AMPK signaling pathway [15]. Hispidulin suppresses the angiogenesis and growth of human pancreatic cancers by targeting the vascular endothelial growth factor receptor [16]. Verbenalin (3) and hastatoside (4) have been reported as sleep-promoting components of $V$. officinalis [17]. In addition, verbenaline (3) showed hepatoprotective activity on experimental liver damage in rodents [18]. Hastatoside (4) was first isolated from $V$. hastata L. and V. officinalis L. [19]. Verbascoside (5), isolated for the first time from Verbascum sinuatum in 1963 [20,21], is active against Staphyloccocus aureus [22], and an inhibitor of protein kinase C [23], it also 
has anti-inflammatory effects in THP-1 cells [24]. Its structure was confirmed by comparing with literature data [21].

From fraction CME-33, a yellowish precipitate was obtained and identified as hispidulin 7-O- $\beta$-D-glucuronopyranoside (6). The presence of this compound has also been reported in $V$. bonariensis [25], but in this work, its complete physical and spectroscopic characteristics are reported: m. p. $182-184^{\circ} \mathrm{C}$; $[\alpha] 25_{\mathrm{D}}-117.4^{\circ}$; IR: $v_{\max }(\mathrm{KBr}): 3332,2922,1656,1602,1509,1488,1459,1351$, 1251, 1182, 1066, 1021, 829, $711 \mathrm{~cm}^{-1}$; ${ }^{1} \mathrm{H}-\mathrm{NMR} 400 \mathrm{MHz}$ (DMSO-d6): $\delta: 12.94$ (1H, s, C5-OH), 7.75 (2H, $\left.\mathrm{d}, J=8 \mathrm{~Hz}, \mathrm{H}-6^{\prime}, \mathrm{H}-2^{\prime}\right), 6.83(1 \mathrm{H}, \mathrm{s}, \mathrm{H}-8), 6.79\left(2 \mathrm{H}, \mathrm{d}, J=12 \mathrm{~Hz}, \mathrm{H}-3^{\prime}, \mathrm{H}-5^{\prime}\right), 6.66(1 \mathrm{H}, \mathrm{s}, \mathrm{H} 3), 5.12(1 \mathrm{H}, \mathrm{d}$, $\left.J=8 \mathrm{~Hz}, \mathrm{H}-1^{\prime \prime}\right), 3.78\left(3 \mathrm{H}, \mathrm{s}, \mathrm{OCH}_{3}\right), 3.70\left(1 \mathrm{H}, \mathrm{d}, J=12 \mathrm{~Hz}, \mathrm{H}-5^{\prime \prime}\right), 3.34\left(2 \mathrm{H}, \mathrm{m}, \mathrm{H}-2^{\prime \prime}, \mathrm{H}-3^{\prime \prime}\right), 3.26(1 \mathrm{H}, \mathrm{dd}$, $\left.J=4,10 \mathrm{~Hz}, \mathrm{H}-4^{\prime \prime}\right) ;{ }^{13} \mathrm{C}-\mathrm{NMR} 100 \mathrm{MHz} \delta: 182.1$ (C-4), 172.5 (C-6"), $164.2(\mathrm{C}-2), 162.2$ (C-4'), 156.3 (C-7), 152.3 (C-5), 152.0 (C-9), 132.3 (C-6), 128.1 (C-2'), 120.0 (C-1'), 115.8 (C-5'), 105.5 (C-10), 102.0 (C-3), 99.4 (C-1"), 93.9 (C-8), $76.6\left(\mathrm{C}-3^{\prime \prime}\right), 73.8\left(\mathrm{C}-5^{\prime \prime}\right), 72.9\left(\mathrm{C}-2^{\prime \prime}\right), 71.9\left(\mathrm{C}-4^{\prime \prime}\right), 60.2\left(-\mathrm{OCH}_{3}\right)$.

From fraction CM-38, a yellowish solid was obtained and identified as pectinolaringenin-7-O$\alpha$-D-glucuronopyranoside (7). There are reports of a compound very similar to (6), the comantoside B, isolated from Comanthosphace japonica (Labiatae) [26] and later by Murata et al. [27]. Contrasting with this, in our work, the flavonoid was identified as the $\alpha$-glucuronide isomer; its characteristics are as follows: m. p. $201-203{ }^{\circ} \mathrm{C} ;[\alpha] 25_{\mathrm{D}}-34.33^{\circ}$; UV: $\lambda_{\max }(\mathrm{MeOH}) 271,330 \mathrm{~nm}$; IR: $v_{\max }(\mathrm{KBr})$ : 3332, 2922, 2839, 1656, 1602, 1488, 1351, 1251, 1182, 1066, $1021 \mathrm{~cm}^{-1}$; ${ }^{1} \mathrm{H}-\mathrm{NMR} 400 \mathrm{MHz}$ (DMSO-d6): $\delta: 12.91\left(1 \mathrm{H}, \mathrm{s}, \mathrm{H}-6^{\prime \prime}\right), 8.05\left(2 \mathrm{H}, \mathrm{d}, J=12 \mathrm{~Hz}, \mathrm{H}-2^{\prime}, \mathrm{H}-6^{\prime}\right), 7.13\left(2 \mathrm{H}, \mathrm{dd}, J=8 \mathrm{~Hz}, \mathrm{H}-3^{\prime}, \mathrm{H}-5^{\prime}\right), 7.03(1 \mathrm{H}$, s, H-8), $6.94(1 \mathrm{H}, \mathrm{s}, \mathrm{H}-3), 5.13\left(1 \mathrm{H}, \mathrm{s}, \mathrm{H}-1^{\prime \prime}\right), 3.86\left(3 \mathrm{H}, \mathrm{s}, \mathrm{O}-\mathrm{CH}_{3}\right), 3.78\left(3 \mathrm{H}, \mathrm{s}, \mathrm{O}-\mathrm{CH}_{3}\right), 3.63(1 \mathrm{H}, \mathrm{d}$, $\left.J=10, \mathrm{H}-5^{\prime \prime}\right), 3.23\left(2 \mathrm{H}, \mathrm{m}, \mathrm{H}-2^{\prime \prime}, \mathrm{H}-3^{\prime \prime}\right), 3.22\left(\mathrm{H}-1, \mathrm{t}, J=9.6, \mathrm{H}-4{ }^{\prime \prime}\right) ;{ }^{13} \mathrm{C}-\mathrm{NMR} 100 \mathrm{MHz}$ 8:182.2 (C-4), $171.8(\mathrm{COOH}), 163.6$ (C-2), 162.3 (C-4'), 156.5 (C-7), 152.3 (C-9), 132.2 (C-6), 128.2 (C-2' y C-6' $), 122.6$ (C-1'), 114.5 (C-3' y C-5'), 105.5 (C-10), 103.2 (C-3), 99.7 (C-1"), 94.1 (C-8), 76.6 (C-2"), 73.8 (C-3"), 72.8 $\left(\mathrm{C}-4^{\prime \prime}\right), 71.7\left(\mathrm{H}-5^{\prime \prime}\right), 60.1\left(\mathrm{O}-\mathrm{CH}_{3}\right), 55.4\left(\mathrm{O}-\mathrm{CH}_{3}\right)$. To the best of our knowledge, this is the first report of hispidulin 7-O- $\beta$-D-glucuronopyranoside (6) and pectolinaringenin-7-O- $\alpha$-D-glucuronopyranoside (7) in the Verbena species.

Except for hispidulin (3), neither the aqueous extract (CAqE), nor compounds (5), (6) or (7) were active against the tested microorganisms (MIC $>100 \mu \mathrm{g} / \mathrm{mL}$ ). The structures of the isolated compounds are shown in Figure 1.

It is worth mentioning that a recent report by Ávila-Reyes et al. [28] only indicates the presence of a flavonoid, a scutellarein glycoside in V. carolina foliar tissues. The authors assessed it by comparison of the HPLC retention time and UV absorptions with a standard of this compound, but it was not isolated. Besides this, that report shows no additional information regarding the major chemical composition of this plant. 


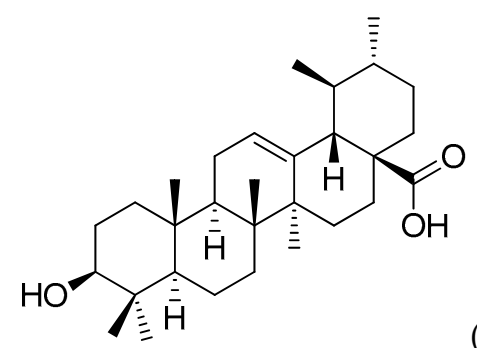

(1)<smiles>C[C@H]1CC(=O)[C@@H]2C(C(=O)O)=COC(OC3OC(CO)C(O)C(O)C3[C@H]2O)[C@@H]1CO</smiles><smiles>COc1c(O)cc2oc(-c3ccc(O)cc3)cc(=O)c2c1O</smiles>

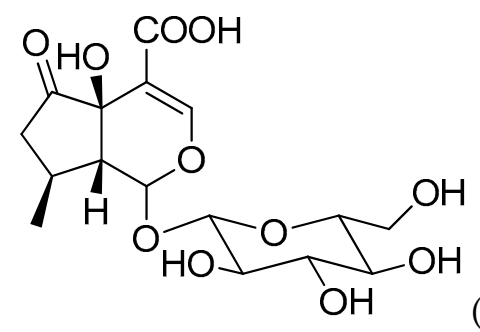

(4)

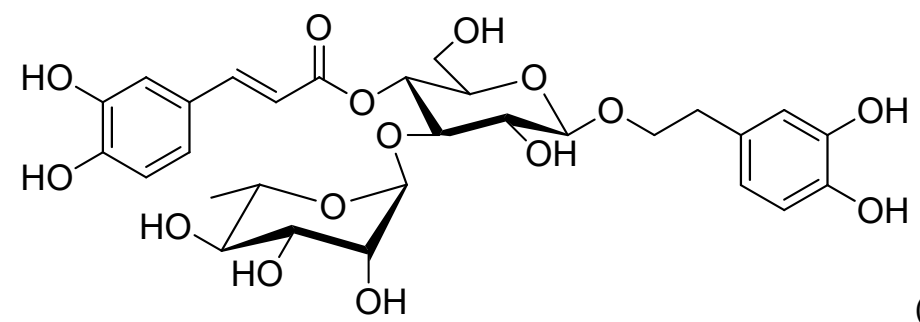<smiles>COc1ccc(-c2cc(=O)c3c(O)c(OC)c(OC4OC(CO)C(O)C(O)C4O)cc3o2)cc1</smiles>

(6)<smiles>COc1c(OC2OC(CO)C(O)C(O)C(O)C2O)cc2oc(-c3ccc(O)cc3)cc(=O)c2c1O</smiles>

(7)

Figure 1. Chemical structures of compounds isolated from $V$. carolina. Ursolic acid (1), hispidulin (2), verbenaline (3), hastatoside (4), verbascoside (5), hispidulin 7-O- $\beta$-D-glucuronopyranoside (7O $\beta \mathrm{GH}$, (6)), pectinolaringenin-7-O- $\alpha$-D-glucuronopyranoside (7).

\subsection{Phenolic Content of V. carolina Extracts}

Total phenolic content in the decoction and in the methanolic extract of V. carolina was estimated from the Folin-Ciocalteu method using gallic acid as the standard. The total amount of polyphenols was higher in the aqueous extract than in the methanol one (23.12 and 13.58 gallic acid equivalents $/ \mathrm{mL}$ ). This is an indication of the antioxidant capacity of the extracts, particularly of the decoction, which is employed in its traditional use. These results agree with our phytochemical analysis where the phenolics hispidulin (2), verbascoside (5), hispidulin 7-O- $\beta$-D-glucuronopyranoside (6) and pectolinaringenin-7-O- $\alpha$-D-glucuronopyranoside (7) were isolated as major compounds.

\subsection{Validation of the Liquid Chromatography (LC) Method and Analysis of Samples}

A reversed phase HPLC system with a dual $\lambda$ UV detector was used to resolve four compounds in the methanol extract of the aerial parts of the plant. The validation of the method was developed according to the ICH guidelines [29]. Compounds (3), (4), (5) and (6) were detected in a sample of the methanolic extract of $V$. carolina (S1) at retention times (RT) of 9.8, 9.4, 11.6 and $13.6 \mathrm{~min}$, respectively. 
Four samples of the last solution were then spiked with a known amount of each of the standards, to verify the retention times.

All the calibration curves showed good linearity within the test ranges $\left(R^{2} \geq 0.999\right)$. The linear regression equations for (3)-(6) were $y=50109.4 x+75972.3, y=30308.0 x+15429.4, y=38331.8 x+$ 3031.2 , and $y=9427.5 x+23078.3$, respectively, indicating an excellent correlation between the peak area and concentration.

The LOD and LOQ values $(\mu \mathrm{g} / \mathrm{mL})$ were 2.20 and $2.8(3), 1.25$ and $2.5(4), 1.40$ and $2.8(5)$, and 1.25 and 5.0 (6).

The linear regression equations corresponding to the accuracy of the method were $y=1.022 x$ $-0.795, y=1.004 x+0.050, y=1.0114 x-0.0412$, and $y=1.0095 x-0.8777$, for (3)-(6). Percentage recoveries of the compounds are indicated in Table 1 . The intra- and inter-day precision RSDs were under $2.0 \%$; the repeatability variation was also less than $2.0 \%$. The results indicate that the method was precise, accurate, and linear for the simultaneous quantification of verbenaline (3), hastatoside (4), verbascoside (5) and hispidulin 7-O- $\beta$-D-glucuronopyranoside (6) in V. carolina.

Table 1. Average recovery of the marker compounds ((3)-(6)) from V. carolina.

\begin{tabular}{ccccc}
\hline Analyte & $\begin{array}{c}\text { Amount Added } \\
(\mu \mathrm{g} / \mathbf{m L})\end{array}$ & $\begin{array}{c}\text { Amount Found } \\
(\mu \mathrm{g} / \mathbf{m L})\end{array}$ & Average Recovery (\%) & RSD (\%) \\
\hline \multirow{3}{*}{ Verbenalin (3) } & 35 & 35.0943 & 100.26 & 1.98 \\
& 70 & 70.5581 & 100.79 & 1.89 \\
\hline \multirow{3}{*}{ Hastatoside (4) } & 105 & 106.6606 & 101.58 & 0.60 \\
\hline \multirow{3}{*}{ Verbascoside (5) } & 20 & 20.216 & 101.08 & 0.48 \\
& 40 & 40.1022 & 100.25 & 1.15 \\
& 60 & 60.4068 & 100.68 & 0.60 \\
\hline \multirow{3}{*}{ 7OßGH, (6) } & 45 & 45.0416 & 100.09 & 1.54 \\
& 135 & 90.7351 & 100.81 & 0.67 \\
& 40 & 136.0689 & 100.78 & 1.55 \\
\hline
\end{tabular}

RSD = Relative standard deviation.

The developed and validated method was successfully applied for the quantification of (3)-(6) in six samples (S1-S6; Table 2).

Table 2. Contents of verbenaline (3), hastatoside (4), verbascoside (5) and hispidulin 7OßGH (6) in six samples of $V$. carolina.

\begin{tabular}{ccccc}
\hline \multirow{2}{*}{ Sample } & \multicolumn{2}{c}{ Concentration (mg/g of Plant) } & \multicolumn{2}{c}{ Mean \pm RSD } \\
\cline { 2 - 5 } & $\mathbf{3}$ & $\mathbf{4}$ & $\mathbf{5}$ & $\mathbf{6}$ \\
\hline S1 & $16.29 \pm 0.89$ & $11.44 \pm 0.52$ & $25.64 \pm 0.67$ & $17.87 \pm 0.98$ \\
S2 & $17.88 \pm 0.05$ & $8.97 \pm 0.16$ & $28.82 \pm 0.23$ & $3.42 \pm 0.49$ \\
S3 & $1.7 \pm 0.00$ & $4.39 \pm 0.01$ & $7.18 \pm 0.03$ & $6.17 \pm 0.25$ \\
S4 & $5.83 \pm 0.13$ & $17.21 \pm 0.37$ & $31.4 \pm 0.96$ & $20.52 \pm 0.90$ \\
S5 & $17.58 \pm 0.07$ & $14.99 \pm 0.07$ & $31.29 \pm 0.09$ & $23.71 \pm 0.41$ \\
S6 & $0.68 \pm 0.03$ & $10.58 \pm 0.10$ & $33.78 \pm 0.36$ & $25.15 \pm 0.52$ \\
\hline \multicolumn{4}{c}{ Mean values $(n=3) ; R S D=$ Relative standard deviation. }
\end{tabular}

In stability tests, the results showed that verbascoside (5) decomposes in the presence of light and heat. Verbenalin (3) is stable below $37^{\circ} \mathrm{C}$ for up to seven days.

Compounds (3)-(6) are useful chemical markers for $V$. carolina because they were found in high quantities in all of the analyzed plant samples except for S3 from Hueyapan, Morelos. This 
sample grows in different environmental conditions (temperature, humidity and altitude). In all cases, verbascoside had the highest concentration. Considering the extent of use of $V$. carolina in Mexican traditional medicine, the content-homogeneity in the samples is of great importance. Furthermore, this study may be useful for the quality control of plant extracts containing compounds (3)-(6). It is also worth noting that (6) was more abundant in a wild sample (S1), than in a cultivated crop (S2) (Table 2 and Figure 2).

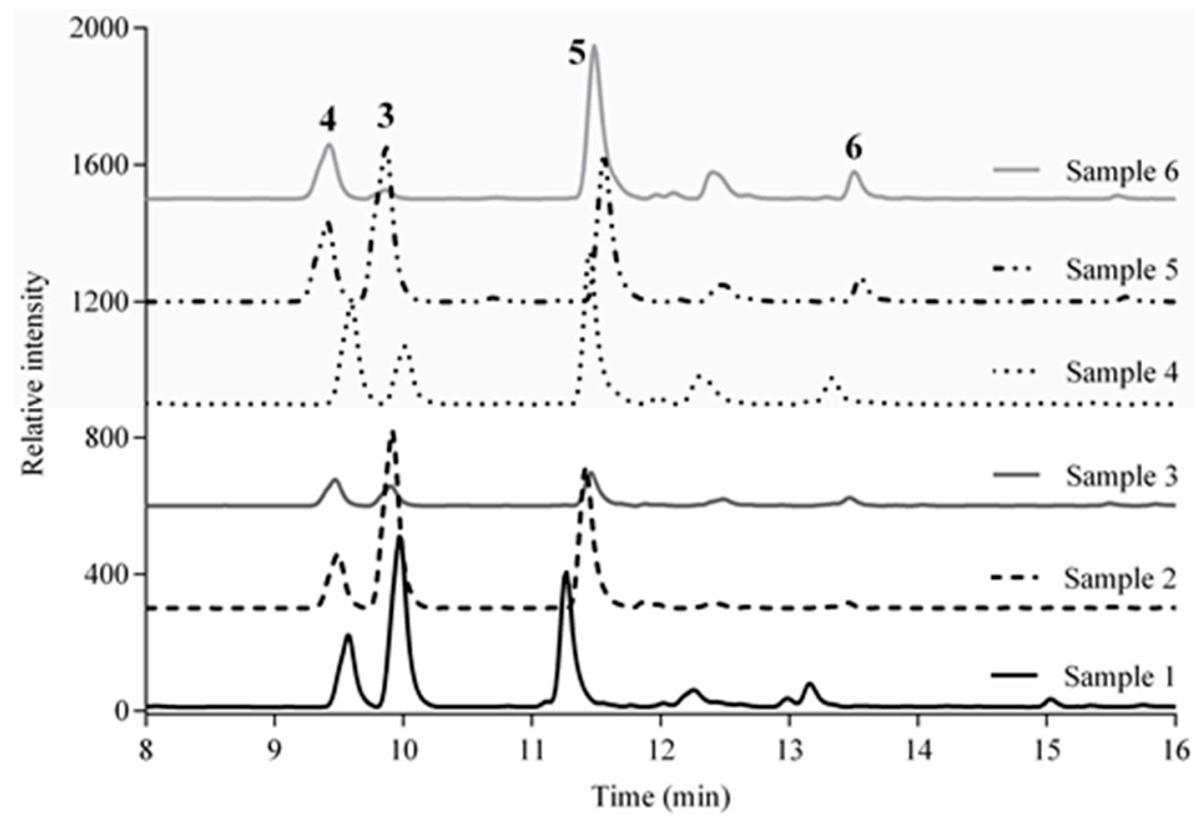

Figure 2. Chromatograms of samples (1)-(6).

\subsection{Scavenging Activity of $V$. carolina Extracts}

The activity of the $V$. carolina extracts was systematically assessed. Depending on the antioxidant ability of the tested samples, the concentrations used ranged from 0.01 to $0.3 \mathrm{mg} / \mathrm{mL}$. There are reports, e.g., Habu and Ibeth [30] in which $0.4 \mathrm{mg} / \mathrm{mL}$ of leave extracts of Newbouldia laevis were used to reach about $85 \%$ of DPPH (2,2-diphenyl-1-picryl-hydrazil-hydrate) radical scavenging. Also, Okoh et al. [31] employed up to $0.5 \mathrm{mg} / \mathrm{mL}$ of seed and shell essential oils obtained from the climbing vine Abrus precatorius L. in ABTS (2,2'-Azino-bis(3-ethylbenzothiazoline-6- sulfonic acid) and DPPH radical assays. The results of three in vitro assays (DPPH, ABTS, FRAP (Ferric reducing ability of plasma)) measuring the antioxidant activities are given in Table 3. The TEAC (Trolox equivalent antioxidant capacity) values of the ABTS and DPPH assays showed that the methanol extract (CME) stabilized the radicals better than the aqueous extract (CAqE) (10.10 vs. 7.10 and 14.20 over 7.50 respectively). Ascorbic acid was used as standard compound in both assays. The results of the FRAP assay are expressed as $\mu \mathrm{mol}$ TEAC per mg of extract; again, CME better stabilizes radicals than CAqE (11.74 vs. 5.49). Quercetin was used as standard in this assay. In all cases, the antioxidant capacity was lower than that of the standards (Table 3). 
Table 3. TEAC values for the DPPH, ABTS and FRAP assays.

\begin{tabular}{|c|c|c|c|c|c|c|}
\hline \multicolumn{3}{|c|}{ DPPH } & \multicolumn{2}{|c|}{ ABTS } & \multicolumn{2}{|c|}{ FRAP } \\
\hline Compound/Extract & $\mathrm{EC}_{50}(\mathrm{mg} / \mathrm{mL})$ & $\begin{array}{c}\text { TEAC } \\
{[\mu \mathrm{mol} \text { trolox/mg extract }]}\end{array}$ & $\mathrm{EC}_{50}(\mathrm{mg} / \mathrm{mL})$ & $\begin{array}{c}\text { TEAC } \\
{[\mu \mathrm{mol} \text { trolox/mg extract }]}\end{array}$ & $\begin{array}{c}\text { TEAC } \\
{[\mu \mathrm{mol} \text { trolox/mg extract }]}\end{array}$ & $\begin{array}{c}\text { AAEAC } \\
{[\mu \mathrm{M} \text { AA } / \mathrm{mg} \text { extract }]}\end{array}$ \\
\hline CAqE & $0.081 \pm 0.0001$ & $7.50 \pm 0.06$ & $0.50 \pm 0.007$ & $7.10 \pm 0.05$ & $3.88 \pm 0.06$ & $5.49 \pm 0.04$ \\
\hline CME & $0.041 \pm 0.00009$ & $14.20 \pm 0.20$ & $0.32 \pm 0.01$ & $10.10 \pm 0.11$ & $13.18 \pm 0.11$ & $11.74 \pm 0.08$ \\
\hline Ascorbic acid & $0.018 \pm 0.00003$ & $23.12 \pm 0.53$ & $0.026 \pm 0.0001$ & $125.13 \pm 0.90$ & - & - \\
\hline Quercetin & & & & & $89.30 \pm 0.90$ & $117.76 \pm 0.61$ \\
\hline
\end{tabular}

Results are represented as the mean values \pm R.S.D. $N=3$; TEAC: Trolox equivalent antioxidant capacity; DPPH: 2,2-diphenyl-1-picryl-hydrazil-hydrate; ABTS

2,2'-Azino-bis(3-ethylbenzothiazoline-6- sulfonic acid; FRAP: Ferric reducing ability of plasma; VCEAC: Ascorbic acid equivalent antioxidant capacity; EC 50 : $50 \%$ effective concentration;

CAqE: aqueous extract; CME: methanolic extract. 


\subsection{Scavenging Activity of V. carolina Bioactive Compounds: Comparison Against Extracts}

Based on the $\mathrm{EC}_{50}$ values of the tested samples, additional tests were performed with specific ROS as $\mathrm{ROO}^{\bullet}, \mathrm{O}_{2}{ }^{\bullet-}, \mathrm{H}_{2} \mathrm{O}_{2}, \mathrm{OH}^{\bullet},{ }^{1} \mathrm{O}_{2}, \mathrm{HClO}$, and $\mathrm{ONOO}^{-}$. The analysis included CAqE, CME, verbascoside (5), verbenalin (3), hastatoside (4) and hispidulin 7-O- $\beta$-D-glucuronopyranoside (glucuronide 7OßGH, (6)).

The methanol extract (CME) was more active than aqueous one (CAqE) in most cases. Regarding the isolated compounds, verbascoside (5) presented the greater quenching, which may be due to the catechol residues in both of its aromatic rings.

Verbenalin (3) was active against $\mathrm{ROO}^{\bullet}, \mathrm{O}_{2}{ }^{\bullet-}, \mathrm{OH}^{\bullet}$ and $\mathrm{ONOO}^{-}$and hastatoside (4) against $\mathrm{ROO}^{\bullet}$, $\mathrm{OH}^{\bullet}$ and $\mathrm{ONOO}^{-}$. These two iridoid compounds were less active than glucuronide $7 \mathrm{O} \beta \mathrm{GH}(6)$ and verbascoside (5). Additionally, (3), (5) and (6) showed higher antioxidant abilities than Tiron (Figure 3).
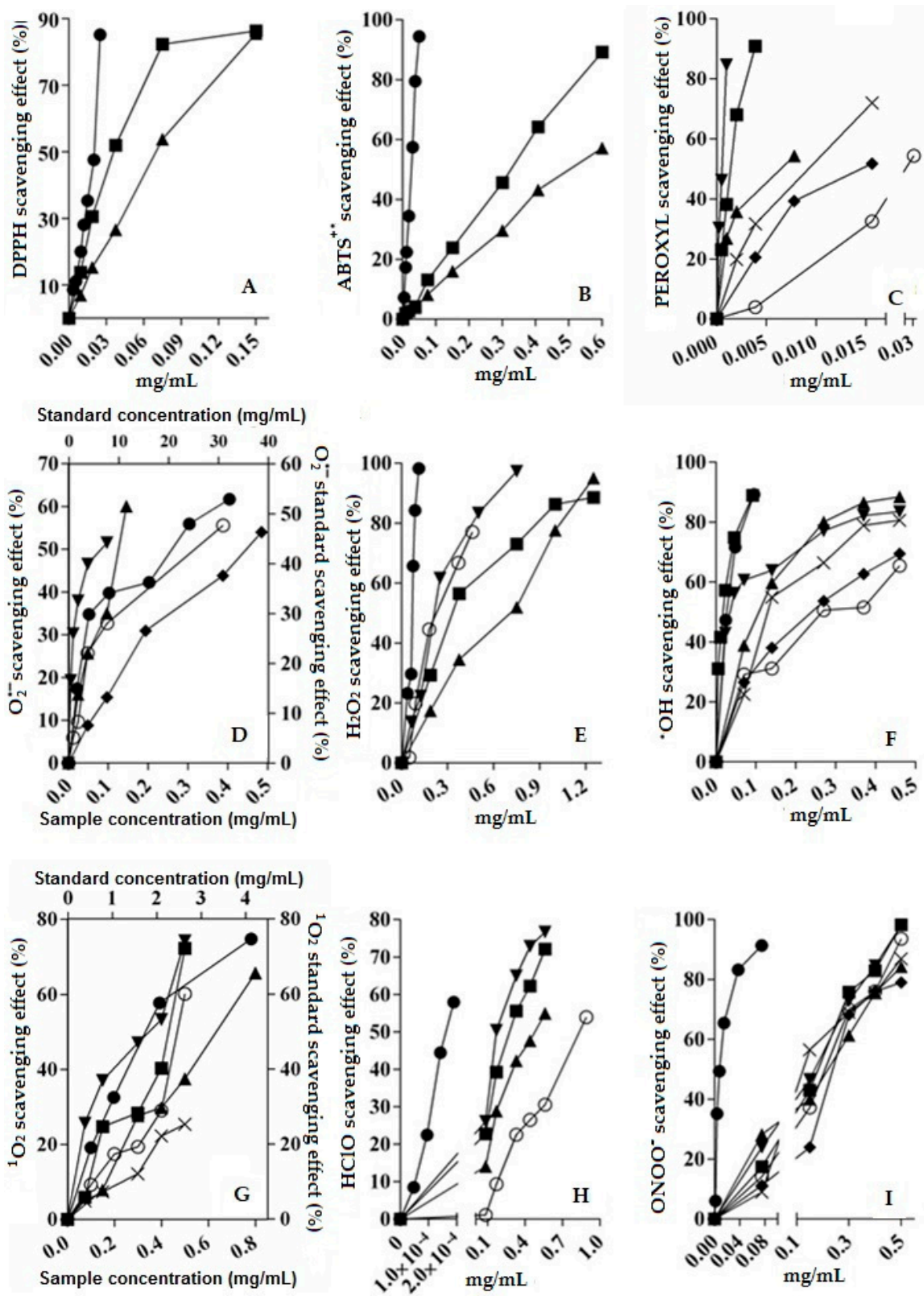

Figure 3. Antioxidant properties of the extracts and the marker compounds (3)-(6) of V. carolina. DPPH (panel A), ABTS (panel B), $\mathrm{ROO}^{\bullet}$ (panel C), $\mathrm{O}_{2}{ }^{\bullet-}$ (panel D), $\mathrm{H}_{2} \mathrm{O}_{2}$ (panel E), $\mathrm{OH}^{\bullet}$ (panel F), ${ }^{1} \mathrm{O}_{2}$ (panel G), $\mathrm{HClO}$ (panel $\mathbf{H}), \mathrm{ONOO}^{-}$(panel I), scavenging capacity of the methanolic extract $(-\mathbf{-})$, aqueous

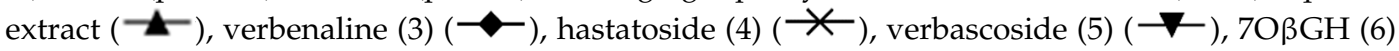
$(\smile)$, reference compounds $(-\bullet)$. 
Regarding the $\mathrm{HClO}$ scavenging, verbascoside (5) showed the highest capacity, followed by CME, $\mathrm{CAqE}$ and glucuronide $7 \mathrm{O} \beta \mathrm{GH}$ (6). Some of the popular uses of the plant such as hepatic protection and wound healing could be attributed to the antioxidant properties showed.

\subsection{Antimicrobial Activity and Acute Toxicity}

The dilution method used in this work is frequently recommended for establishing the relative antimicrobial potency of complex plant extracts and their antimicrobial spectrum [32]. There is not a uniform criterion to compare the antimicrobial activity of extracts with that of reference antibiotics; literature data indicate that MIC values between 2.5 and $15 \mathrm{mg} / \mathrm{mL}$ [33] may lead to strong antimicrobial compounds [34,35].

Then tested extracts showed antimicrobial activity against the dermatophytes (T. mentagrophytes and T. rubrum), in addition, the methanol extract (CME) was active against C. albicans (MIC values of $0.7 \mathrm{mg} / \mathrm{mL}$ ). All the extracts (CAqE, CDE and CME) were only slightly active against Enterococcus faecalis and Staphylococcus aureus (MIC $1.5 \mathrm{mg} / \mathrm{mL}$ ), the methanol extract (CME) also showed low activity against Salmonella typhi (MIC of $1.5 \mathrm{mg} / \mathrm{mL}$ ). No antibacterial activity against Escherichia coli was observed in any of the extracts or isolated compounds.

For the acute toxicity test, doses of 10,100 and $1000 \mathrm{mg} / \mathrm{kg}$ of CAqE in the first phase, and 1600, 2900 and $5000 \mathrm{mg} / \mathrm{kg}$ in the second phase were employed; an LD 50 value higher than $5000 \mathrm{mg} / \mathrm{kg}$ was calculated using the geometric mean of the doses for which none of the animals died ( $0 / 3$ deaths were found), and none of the organs analyzed after the experiment showed physical anomalies. Hence, CAqE of V. carolina could be regarded as non-toxic [36].

\section{Materials and Methods}

\subsection{Chemicals and Materials}

Sodium pyruvate, dimethyl thiourea (DMTU), ascorbic acid, 2,2' -azinobis-(3-ethylbenzothiazoline6-sulfonic acid) (ABTS), 2,2-diphenyl-1-picrylhydrazyl (DPPH), dimethylsulfoxide (DMSO), nitroblue tetrazolium (NBT), potassium nitrite $\left(\mathrm{KNO}_{2}\right)$, manganese dioxide $\left(\mathrm{MnO}_{2}\right)$, diethylene triamine pentaacetic acid (DTPA), DL-penicillamine, potassium persulfate $\left(\mathrm{K}_{2} \mathrm{SO}_{4}\right)$, sodium carbonate $\left(\mathrm{Na}_{2} \mathrm{CO}_{3}\right)$, 4-aminobenzoic-acid, gallic acid, 4-(2-hydroxyethyl)-1-piperazineethanesulfonic acid, 6-hydroxy-2,5,7,8-tetramethylchroman-2-carboxylic acid, N-acetyl-3,7-dihydroxyphenoxazine (Amplex Red), 2,2'-azobis(2-amidinopropane) dihydrochloride (AAPH), iron chloride hexahydrate, dichloro-dihydro-fluorescein diacetate (DCDHF-DA), 1,3-diphenyl isobenzofurane (DPBF), fluorescein, phenazine methosulfate (PMS), $\beta$-nicotinamide adenine dinucleotide (NADH), horseradish peroxidase, Folin-Ciocalteu reagent, 4-(2-hydroxyethyl)-1-piperazineethanesulfonic acid (HEPES), 4,5-dihydroxy-1,3-benzenedisulfonic acid disodium salt monohydrate (Tiron), 2,4,6-Tris(2-pyridyl)-s-triazine (TPTZ) and terephthalic acid (TA) were purchased from Sigma Aldrich (St. Louis, MO, USA), and gentamicin and miconazole were purchased from Sigma Aldrich (St. Louis, MO, USA). Sodium hydroxide was obtained from Meyer (Mexico City, Mexico). Absolute ethanol, hydrogen peroxide $\left(\mathrm{H}_{2} \mathrm{O}_{2}\right)$, methanol $(\mathrm{MeOH})$, ethylenediamine-tetraacetic acid disodium salt (EDTA), sodium hypochlorite $(\mathrm{NaOCl})$ and sodium nitrite $\left(\mathrm{NaNO}_{2}\right)$ were purchased from JT Baker (Mexico City, Mexico). All other chemicals were reagent grade and commercially available. Acetonitrile (LiChrosolv $\left.{ }^{\circledR}\right)$ was HPLC grade and deionized water was obtained from a MilliQ System. Pure verbenalin (3), hastatoside (4), verbascoside (5) and hispidulin 7-O- $\beta$-D-glucuronopyranoside (6) (>98\% determined by HPLC) were isolated from Verbena carolina and used for the calibration. Their identities were confirmed based on spectral data (IR, UV, NMR and MS) [5,7-9].

\subsection{Plant Material}

Aerial parts of Verbena carolina were either collected or locally purchased as follows: Samples 1 (S1) and 2 (S2) from Mercado de Sonora (wild and cultivated, respectively, 2013), sample 3 (S3) from 
Hueyapan, Morelos, Mexico (April 2005), samples 4 (S4), 5 (S5) and 6 (S6) from State of Mexico (2013, S4: $19^{\circ} 5^{\prime} 17.64^{\prime \prime} \mathrm{N}, 99^{\circ} 33^{\prime} 40.48^{\prime \prime} \mathrm{O}$, at 2600 masl, S5: $19^{\circ} 5^{\prime} 26.85^{\prime \prime} \mathrm{N}, 99^{\circ} 34^{\prime} 41.41^{\prime \prime} \mathrm{O}$, at 2800 masl, and S6: $19^{\circ} 6^{\prime} 51.45^{\prime \prime} \mathrm{N}, 99^{\circ} 35^{\prime} 9.15^{\prime \prime} \mathrm{O}$, at $\left.2600 \mathrm{masl}\right)$. The material was identified by M. Avilés and M. Fuentes and a voucher specimen (INAHM-2018) was deposited in the Herbarium of the Instituto Nacional de Antropología e Historia Morelos (INAHM) in the Medicinal Botanical Garden in the city of Cuernavaca, Morelos, Mexico.

\subsection{Preparation of the Extracts and Isolation of Compounds}

The air-dried aerial parts of V. carolina L. $(1.3 \mathrm{~kg}, \mathrm{~S} 1)$ were ground into powder and successively macerated at room temperature with n-hexane, dichloromethane, acetone and methanol ( $48 \mathrm{~h}$ with $4 \mathrm{~L}$ for each solvent) and filtered. This was repeated thrice and each extract was combined and evaporated under vacuum to yield the corresponding hexane (CHE, $17.7 \mathrm{~g}$ ), dichloromethane (CDE, 174.9 g), acetone (CAE, $90 \mathrm{~g}$ ) and methanol (CME, $131.0 \mathrm{~g}$ ) syrupy residues. Another batch of V. carolina (50 g, S1) was extracted by decoction with water and concentrated in vacuo to give $11 \mathrm{~g}$ of a concentrated residue (CAqE). CAqE, $\mathrm{CDE}$ and $\mathrm{CME}$ showed $\mathrm{MIC}$ values ranging between 0.7 and $3.0 \mathrm{mg} / \mathrm{mL}$ in the antimicrobial assay, thus, a bioguided fractionation was done based on the antimicrobial properties, particularly the activity against dermatophytes, using the agar dilution method. CDE (174.8 g) was subjected to column chromatography over silica gel $60(1.0 \mathrm{~kg})$. A sample of fraction CDE-3 (20 mg), which eluted with hexane-ethyl acetate (EtOAc) 90:10, was methylated with $2 \mathrm{~mL}$ of $5 \% \mathrm{KOH}$ in methanol at $80{ }^{\circ} \mathrm{C}$ for $1 \mathrm{~h}$ in a sealed tube. Then, $100 \mu \mathrm{L}$ of boron trifluoride $\left(\mathrm{BF}_{3}\right)$ were added and the mixture heated for an additional hour at $80^{\circ} \mathrm{C}$. After cooling at room temperature, $4 \mathrm{~mL}$ of water were added and the mixture partitioned with toluene-hexane $(8: 2 v / v)$. The residue of the evaporation of the organic layer was analyzed by gas chromatography-mass spectrometry (GC-MS); a mixture of fatty acids was identified. From fraction CDE-13 (1.6 g, hexane-EtOAc 55:45 v/v) a white powder precipitated; it was recrystallized with $\mathrm{MeOH}$ and identified as ursolic acid (1) by spectroscopic techniques [6].

In a separate experiment, CAE $(90 \mathrm{~g})$ was dissolved in distilled water $(1 \mathrm{~L})$, filtered and successively partitioned with EtOAc and n-butanol. This last extract was evaporated (13.9 g) and subjected to column chromatography $\left(\mathrm{SiO}_{2}, 231 \mathrm{~g}\right)$ with a gradient of $\mathrm{CH}_{2} \mathrm{Cl}_{2} / \mathrm{MeOH}(10: 0-0: 10 v / v)$. Fractions of $100 \mathrm{~mL}$ each were collected and pooled based on the system of solvents used to yield ten main fractions (CAE-1-CAE-10). From fraction CAE-4 (680 mg), a yellow powder spontaneously precipitated, which upon EtOH recrystallization gave $200 \mathrm{mg}$ of hispidulin (2).

In a third experiment, $50 \mathrm{~g}$ of CME were subjected to column chromatography $\left(\mathrm{SiO}_{2}, 200 \mathrm{~g}\right)$, eluting with gradients of $\mathrm{CH}_{2} \mathrm{Cl}_{2} / \mathrm{MeOH}(10: 0-0: 10 \mathrm{v} / \mathrm{v})$ to yield 40 primary fractions (F1-F40) of $100 \mathrm{~mL}$ each. Verbenaline (3) was obtained from fraction CME-15 (9.5:5) as a white solid (700 mg) and was recrystallized with n-hexane-EtOAc; hastatoside (4) was also obtained as a white solid (50 mg) from fraction CME-20 $\left(\mathrm{CH}_{2} \mathrm{Cl}_{2} / \mathrm{MeOH}\right.$ 9:1 v/v); verbascoside (5) was obtained from fraction CME-30 $\left(\mathrm{CH}_{2} \mathrm{Cl}_{2} / \mathrm{MeOH}\right.$ 8:1 v/v) as a brown solid $(1 \mathrm{~g})$. Compounds (4) and (5) were purified with a secondary $\mathrm{SiO}_{2}$ column chromatography (EtOAc 100\%). Hispidulin 7-O- $\beta$-D-glucuronopyranoside $(7 \mathrm{O} \beta \mathrm{GH}$, (6)) and pectinolaringenin-7-O- $\alpha$-D-glucuronopyranoside (7) were respectively isolated from fractions CME-33 (20 mg) and $38(40 \mathrm{mg})\left(\mathrm{CH}_{2} \mathrm{Cl}_{2}-\mathrm{MeOH}, 8.0: 2.0 \mathrm{v} / \mathrm{v}\right)$, as yellowish precipitates. The chemical identities of all the isolated compounds were confirmed by spectroscopic techniques.

\subsection{Total Phenolics Quantitation}

Total polyphenols were determined in the aqueous (CAqE) and methanolic (CME) extracts by the Folin-Ciocalteu method. Each extract solution $(20 \mu \mathrm{L})$ containing $1 \mathrm{mg}$ of plant extract was mixed with $160 \mu \mathrm{L}$ of distilled water and $20 \mu \mathrm{L}$ of the Folin-Ciocalteu reagent. The mixture was incubated for $8 \mathrm{~min}$ at room temperature in the dark, and $10 \mu \mathrm{L}$ of sodium carbonate $(20 \%)$ were added. The mixture was incubated for $1 \mathrm{~h}$ at room temperature and absorbance at $760 \mathrm{~nm}$ was measured. Total polyphenols were expressed as $\mathrm{mg}$ of gallic acid equivalents/g of extract after interpolating in a calibration curve. 


\subsection{Equipment and Chromatographic Conditions}

IR spectra were obtained using KBr disks or films on a Perkin-Elmer FT 1605 spectrophotometer. NMR spectra including COrrelation SpectroscopY (COSY), Nuclear Overhauser Effect SpectroscopY (NOESY), Heteronuclear Multiple Bond Correlation (HMBC) and Heteronuclear Single Quantum Correlation (HSQC) experiments were acquired on a Varian Unity INOVA at 300 or $400 \mathrm{MHz}\left({ }^{1} \mathrm{H}\right)$ and 75 or $100 \mathrm{MHz}\left({ }^{13} \mathrm{C}\right)$. Electron impact mass spectrometry (EI-MS) was recorded on a JEOL SX 102A mass spectrometer and optical rotations were determined on a Perkin-Elmer Model 241 polarimeter. For open column chromatography, $\mathrm{SiO}_{2} 60$ (70-230 mesh, Merck, Germany) was used and silica gel 60 F254 (Merck) for TLC.

\subsection{Preparation of Stock and Working Solutions for HPLC}

Stock solutions of compounds (3)-(6) were prepared in methanol at 210, 120, 270 and $240 \mu \mathrm{g} / \mathrm{mL}$, respectively. The calibration curves for each standard were made by stepwise dilution of the stock solutions to obtain seven different concentrations in the range of ( $\mu \mathrm{g} / \mathrm{mL}$ ): 8.8 to 210 (3), 5 to 120 (4), 11 to 270 (5) and 10 to 240 (6).

Air-dried parts of $V$. carolina were ground and sifted through a $1.4 \mathrm{~mm}$ sieve. The obtained powder $(50 \mathrm{mg}$ ) was mixed with $3 \mathrm{~mL}$ of methanol in a conical flask and sonicated for $15 \mathrm{~min}$. The extract was centrifuged $(15 \mathrm{~min}, 3000 \times \mathrm{g})$ and the supernatant diluted to $10 \mathrm{~mL}$. Then, it was filtered through a $0.45 \mu \mathrm{m}$ polyvinylidene difluoride (PVDF) membrane syringe filter prior to injection into the HPLC system.

\subsection{HPLC Analytical Method}

The HPLC system (Waters Corp., Milford MA, USA) consisted of a 515 pump, an AS-2055PLUS automated injector (Jasco), a 680 automated gradient controller, a 2487 two-channel UV/visible (VIS) detector, and a computerized data station equipped with the Waters Millennium software. All the analyses were performed using a C18 stationary phase in a PrincetonSPHER $100 \AA$ A column $(150 \times 4.6 \mathrm{~mm}$ I.D.; $3 \mu \mathrm{m}$ particle size) operating at $30^{\circ} \mathrm{C}$. The mobile phase consisted of $0.1 \%$ acetic acid in water (A) and acetonitrile (B) with the following gradient $(v / v)$ : From 96:4 to 80:20 in $8 \mathrm{~min}$; then to $60: 40$ in $6 \mathrm{~min}$, to 35:65 in $2 \mathrm{~min}$ and finally to 0:100 in $4 \mathrm{~min}$ at $0.7 \mathrm{~mL} / \mathrm{min}$. Compounds (3)-(5) were monitored at 240 and $330 \mathrm{~nm}$ (volume of injection $20 \mu \mathrm{L}$ ). Each run was followed by a $5 \mathrm{~min}$ wash with $100 \%$ acetonitrile and an equilibration period of $15 \mathrm{~min}$. The compounds were identified based on the retention time and by spiking with standards under the same conditions.

The method was validated according to the International Council for Harmonisation (ICH) guidelines. The following characteristics were evaluated: Selectivity, accuracy, precision, linearity, and limits of detection (LOD) and quantitation (LOQ). The selectivity was assessed based on the peak purity and resolution from the nearest eluting peaks.

The calibration curves were prepared in the concentration range expected for each compound as described in Section 3.6. The correlation coefficient was obtained from the peak area vs. concentration plots using the Statgraphics Centurion XV software (Statpoints Technologies, Warrenton, VA, USA).

The precision was determined by evaluating the repeatability and intermediate precision using the standard addition method. For the former a set of six replicate analyses of the same solution containing $70,40,90$ or $80 \mu \mathrm{g} / \mathrm{mL}$ of (3)-(6), respectively, was evaluated in a single day. The intermediate precision was estimated from a set of six-fold analyses of the same (3)-(6) solution on different days and by two analysts. The standard deviation (SD) and coefficient of variation (RSD) were calculated for each analysis

Recovery experiments were performed to assess the accuracy of the method. Three concentrations (low, medium, and high) were selected over the linear range. All the analyses were performed by spiking (3)-(6) to the samples, and then evaluating the recovery. The limits of detection (LOD) and quantitation (LOQ) were respectively calculated as 3.3 and 10 times the SD. 
The validated analytical method was used for the simultaneous determination of (3)-(6) in six batches sampled from several provinces (S1-S6). The six dry samples (S1-S6) of V. carolina were powdered, extracted, and analyzed as described in Section 3.6.

The stability of the samples was evaluated under different conditions: Room temperature, darkness, refrigeration, refrigeration and darkness, and $37^{\circ} \mathrm{C}$ in darkness. Each one was analyzed at 24 and $72 \mathrm{~h}$, and 8 days.

\subsection{Radical Scavenging Tests}

To evaluate the DPPH scavenging ability, the method described by Cheng et al. [37] was used employing six concentrations of CAqE and CME ranging from 0.01 to $0.3 \mathrm{mg} / \mathrm{mL}$ and $100 \mu \mathrm{L}$ of a solution of methanol and DPPH $(0.208 \mathrm{mM})$. The control sample contained distilled water. After incubation for $20 \mathrm{~min}$ at room temperature and in the dark the absorbance was recorded at $515 \mathrm{~nm}$. The scavenging capacity is given as the percentage (\%) of DPPH scavenged, calculated as [(optical density of control—optical density of compound)/(optical density of control) $\times 100]$. EC 50 values were obtained correlating the DPPH radical scavenging percent and the concentration of samples. The ability of $V$. carolina extracts to scavenge DPPH was compared with that of ascorbic acid.

ABTS radical cation was generated by the incubation of $7 \mathrm{mM}$ ABTS with $2.5 \mathrm{mM}$ potassium persulfate in the dark at room temperature for $12-16 \mathrm{~h}$ [38]. The ABTS ${ }^{\bullet+}$ solution was diluted to an absorbance of 0.70 at $734 \mathrm{~nm}$ in methanol. Then, $20 \mu \mathrm{L}$ of CAqE or CME extracts ranging from 0.01 to $0.6 \mathrm{mg} / \mathrm{mL}$ were added to $180 \mu \mathrm{L}$ of the $\mathrm{ABTS}^{\bullet+}$ solution and the absorbance was read after six min. Ascorbic acid was used as a reference for the scavenging activity.

For the ferric reducing antioxidant power (FRAP) assay, the method by Benzie and Strain [39] was employed. The FRAP solution was prepared mixing a $300 \mathrm{mM}$ acetate buffer solution (adjusted to $\mathrm{pH}$ 3.6) with $20 \mathrm{mM}$ ferric chloride hexahydrate dissolved in distilled water and $10 \mathrm{mM}$ TPTZ dissolved in $40 \mathrm{mM} \mathrm{HCl}$. Afterwards, $20 \mu \mathrm{L}$ of five concentrations of either CAqE or CME from 0.01 to $1.0 \mathrm{mg} / \mathrm{mL}$ were added to $180 \mu \mathrm{L}$ of the FRAP solution. After incubation for $30 \mathrm{~min}$ at room temperature in darkness, the absorbance was recorded at $595 \mathrm{~nm}$. Trolox and ascorbic acid were used to obtain the calibration curves and quercetin as the standard compound.

\subsection{Reactive Oxygen Species (ROS)-Scavenging Measurements}

The ROS-scavenging capacity of the aqueous (CAqE) and methanol (CME) extracts were tested in seven in vitro assays for the following species: Peroxyl radical $\left(\mathrm{ROO}^{\bullet}\right)$, superoxide radical $\left(\mathrm{O}_{2}{ }^{\bullet-}\right)$, hydrogen peroxide $\left(\mathrm{H}_{2} \mathrm{O}_{2}\right)$, hydroxyl radical $\left({ }^{\bullet} \mathrm{OH}\right)$, singlet oxygen $\left({ }^{1} \mathrm{O}_{2}\right)$, hypochlorous acid $(\mathrm{HClO})$ and peroxynitrite $\left(\mathrm{ONOO}^{-}\right)$. All the measurements were carried out in 96 wells plates and based on previously reported methods with minor modifications and they were assayed in triplicate. Briefly, for the peroxyl radical scavenging activity, the method was based on the peroxyl-radical mediated damage of fluorescein $[40,41]$. Samples were tested at nine concentrations from 0.002 to $0.5 \mathrm{mg} / \mathrm{mL}$ in distilled water. Readings were recorded at $535 \mathrm{~nm}$ (emission) and $485 \mathrm{~nm}$ (excitation). Trolox was used for the calibration curves.

For the superoxide scavenging analysis, a colorimetric assay was performed as follows: $10 \mu \mathrm{L}$ of DMSO were added to $1.14 \mathrm{~mL}$ of $20 \mathrm{mM}$ HEPES buffer, pH 7.2 containing $5 \mu \mathrm{M}$ PMS, $50 \mu \mathrm{M}$ NBT and samples (CAqE and CME) at six concentrations from 0.5 to $5 \mathrm{mg} / \mathrm{mL}$. To the mixture, $50 \mu \mathrm{L}$ of $2.5 \mathrm{mM}$ NADH solution were added to initiate the generation of the superoxide anion. After the addition, the optical density at $560 \mathrm{~nm}$ was recorded [42]. Tiron was used as the standard for the calibration curves.

The hydrogen peroxide scavenging fluorimetric assay relies on the reaction between Amplex Red and $\mathrm{H}_{2} \mathrm{O}_{2}$, which is catalyzed by horseradish peroxidase [43]. The aqueous solutions of $\mathrm{CAqE}$ and CME at six concentrations ( 0.5 to $5 \mathrm{mg} / \mathrm{mL}$ ) were mixed with $10 \mu \mathrm{M} \mathrm{H}_{2} \mathrm{O}_{2}$. After 30 min, the $\mathrm{H}_{2} \mathrm{O}_{2}$ concentration was estimated by measuring the fluorescence using 530/25 excitation and a 590/35 emission filter. Sodium pyruvate was used as the standard. 
The hydroxyl radical scavenging capacity was evaluated according to [43]. The $\mathrm{OH}^{\bullet}$ was generated by the $\mathrm{Fe}^{3+}-\mathrm{EDTA}-\mathrm{H}_{2} \mathrm{O}_{2}$ reaction. Terephtalic acid, which is not fluorescent, was used to assess the generation of the radical since it reacts with $\mathrm{OH}^{\bullet}$ to form the fluorescent 2-hydroxy-TA. Briefly, $180 \mu \mathrm{L}$ of the following reaction mixture: $0.2 \mathrm{mM}$ ascorbic acid, $0.2 \mathrm{mM} \mathrm{FeCl}, 0.208 \mathrm{mM}$ EDTA, and $1 \mathrm{mM} \mathrm{H}_{2} \mathrm{O}_{2}, 1.4 \mathrm{mM}$ TA in $20 \mathrm{mM}$ phosphate buffer ( $\mathrm{pH}$ 7.4) were mixed with $20 \mu \mathrm{L}$ of different concentrations of CAqE and CME, ranging from 0.5 to $5 \mathrm{mg} / \mathrm{mL}$. The increase in fluorescence emission at $432 \mathrm{~nm}$ was measured for $30 \mathrm{~min}$ after a $326 \mathrm{~nm}$ excitation. DMTU was used as the standard.

To measure the singlet oxygen scavenging activity, a solution of ethanol, $1 \mathrm{mM} \mathrm{H}_{2} \mathrm{O}_{2}, 3 \mu \mathrm{M}$ $\mathrm{NaOCl}$, and $1 \mu \mathrm{M}$ DPBF was mixed with five aqueous solutions of CAqE and CME $(0.3125-5 \mathrm{mg} / \mathrm{mL})$. The plates were incubated for $10 \mathrm{~min}$ at $25^{\circ} \mathrm{C}$ in the dark, then $150 \mu \mathrm{L}$ of ethanol were added to each well and the fluorescence emission at $455 \mathrm{~nm}$ was measured after excitation at $410 \mathrm{~nm}$ [43]. Data were collected every minute for $10 \mathrm{~min}$. Lipoic acid was used as the standard.

For the hypoclorous acid scavenging assay, 0.5 to $5 \mathrm{mg} / \mathrm{mL}$ solutions of CAqE or CME were mixed with $30 \mu \mathrm{L}$ of $0.05 \mathrm{mM} \mathrm{HClO}$ and with $30 \mu \mathrm{L}$ of $0.1 \mathrm{mM}$-aminobenzoic acid. The fluorescence was registered for $15 \mathrm{~min}$ using filters for a $280 \mathrm{~nm}$ excitation and $340 \mathrm{~nm}$ emission. Ascorbic acid was used as the standard.

For the peroxynitrite scavenging assay, $\mathrm{CAqE}$ or $\mathrm{CME}$ were tested at concentrations from 0.1 to $5 \mathrm{mg} / \mathrm{mL}$ in a solution containing $33 \mu \mathrm{M}$ DTPA, $100 \mu \mathrm{M}$ DCDHF-DA, and $20 \mu \mathrm{M} \mathrm{ONOO}^{-}$in $0.1 \mathrm{M}^{-}$ sodium phosphate buffer $\mathrm{pH}$ 7.4. Fluorescence was measured at $528 \mathrm{~nm}$ after excitation and at $485 \mathrm{~nm}$ emission every five min for $30 \mathrm{~min}$ [41]. Penicillamine was used as standard. Peroxynitrite was synthesized as follows: $5 \mathrm{~mL}$ of an acidic solution of $0.7 \mathrm{M} \mathrm{H}_{2} \mathrm{O}_{2}$ (in $0.6 \mathrm{M} \mathrm{HCl}$ ) were mixed with $5 \mathrm{~mL}$ of $0.6 \mathrm{M} \mathrm{KNO}_{2}$ on an ice bath for $1 \mathrm{~s}$ before the reaction was quenched with $5 \mathrm{~mL}$ of ice-cold $1.2 \mathrm{M}$ $\mathrm{NaOH}$. Residual $\mathrm{H}_{2} \mathrm{O}_{2}$ was removed using a column of granular $\mathrm{MnO}_{2}$ prewashed with $1.2 \mathrm{M} \mathrm{NaOH}$ and the filtered solution was then left overnight at $-20^{\circ} \mathrm{C}$. The resulting yellow liquid layer on the top of the frozen mixture was collected for the assays. The concentration of $\mathrm{ONOO}^{-}$was determined before each experiment at $302 \mathrm{~nm}$ considering a molar extinction coefficient of $1670 \mathrm{M}^{-1} \mathrm{~cm}^{-1}$.

\subsection{Antibacterial and Antifungal Activity}

For the antibacterial and antifungal assays, the following strains, purchased from American Type Culture Collection (ATCC, Manassas, VA, USA), were used: Staphylococcus aureus ATCC 6358; Enterococcus faecalis ATCC 10231; Escherichia coli ATCC 8937; Salmonella typhi ATCC 06539; the filamentous fungi Trichophyton mentagrophytes ATCC 28185 and Trichophyton rubrum ATCC 28188 and Candida albicans ATCC 10231. The antifungal assay was done in Petri dishes (Falcon) [44,45]. The antibacterial assay was carried out via the agar dilution method [46]. Both the antibacterial and antifungal activities were measured by determining the MIC of CAqE and compounds (1)-(7).

For the antibacterial assay, samples were dissolved in DMSO $(2 \% v / v)$ at $10 \mathrm{mg} / \mathrm{mL}$. Then, the solutions were diluted to reach final concentrations of 1.5 to $400 \mu \mathrm{g} / \mathrm{mL}$. The inoculum for each organism was prepared from cultures containing 108 colony-forming units (CFU)/mL. The diluted (1:20) inoculum was applied as a spot using a calibrated loop that delivered $0.002 \mathrm{~mL}$, resulting in a circular spot of 5-8 mm diameter with $104 \mathrm{CFU}$. The plates were incubated for $24 \mathrm{~h}$ at $37^{\circ} \mathrm{C}$. Gentamicin $(2.5-120 \mu \mathrm{g} / \mathrm{mL})$ (Sigma) was used as the standard. Observations were performed by duplication. Results are expressed as the lowest concentration of plant extract that completely suppresses colony growth on the agar.

For the antifungal assay, the samples and reference compounds, Nystatin (Merck) and Miconazole (Sigma), were used in two-fold serial dilutions yielding concentrations in the range from 1.5 to $400 \mu \mathrm{g} / \mathrm{mL}$ for extracts and from 1.0 to $128 \mu \mathrm{g} / \mathrm{mL}$ for pure compounds; $8 \mu \mathrm{g} / \mathrm{mL}$ and $4 \mu \mathrm{g} / \mathrm{mL} \mathrm{for}$ Nystatin and Miconazole, respectively. Final concentrations of DMSO in the test were less than 2\% $(v / v)$. A final inoculum of $105 \mathrm{cell} / \mathrm{mL}$ for Candida albicans and $106 \mathrm{spore} / \mathrm{mL}$ for the filamentous fungi was spouted on top of the solidified agar with a loop calibrated to deliver $0.005 \mathrm{~mL}$. Experiments were carried out during duplication with incubation at $29^{\circ} \mathrm{C}$. The fungal growth was assessed in control 
plates prepared without any test samples after 24,48 and $72 \mathrm{~h}$, depending on the incubation period required for a visible growth: $24 \mathrm{~h}$ for Candida albicans, and $72 \mathrm{~h}$ for the dermatophytes.

\subsection{Animals}

ICR male mice (25-30 g) obtained from Centro UNAM-Harlan (Harlan México, S.A. de C.V.) were used for the toxicity studies. Procedures involving animals and their care were conducted according to protocols approved by the Universidad Nacional Autónoma de México, Facultad de Química Animal Care Committee under the Mexican Official Norm for Animal Care and Handling (NOM-062-ZOO-1999) and in compliance with the international rules on care and use of laboratory animals.

\subsection{Acute Toxicity Study in Mice}

Food was withheld $12 \mathrm{~h}$ before the experiment, but animals had water ad libitum. Two groups of three mice each were orally fed with the V. carolina decoction (CAqE) at doses of 10,100 and $1000 \mathrm{mg} / \mathrm{kg}$ in a first phase, and 0,1600, 2900 and $5000 \mathrm{mg} / \mathrm{kg}$ in a second phase. Animals were observed daily for 14 days for mortality, toxic effects and/or changes in behavioral pattern, according to Lorke's method [36,47]. At the end of the experiments the animals were euthanized in $\mathrm{a}_{2}$ chamber. A post mortem analysis of all animals was practiced evaluating the physical characteristics of the main vital organs (heart, lungs, liver, stomach, bowels and kidneys).

\subsection{Statistical Analysis}

Data are expressed as mean \pm SEM (standard error of the mean) and were compared against the blank tube without $V$. carolina extracts. The scavenging capacity was expressed as the $50 \%$ effective concentration $\left(\mathrm{EC}_{50}\right)$ value, which denotes the concentration of $V$. carolina extracts, required for a $50 \%$ reduction in the oxidizing effect relative to the blank tube.

\section{Conclusions}

The beneficial effect of $\mathrm{CAqE}$ for dermatological conditions may be justified by the results obtained in the antifungal and antioxidant assays. With respect to antimicrobial activity, hispidulin (2) was active against the fungi T. mentagrophites, T. rubrum and C. albicans. Regarding the scavenging effect, in general, individual compounds were more effective than extracts. The results also support the widespread use of this plant in traditional medicine.

A simple and reliable RP-HPLC analytical method was developed and fully validated for the quantification of verbenaline (3), hastatoside (4), verbascoside (5) and hispidulin 7OßGH (6) in Verbena carolina. The method was used to establish seasonal and geographical variations of the markers in $V$. carolina from several regions of Mexico. These marker compounds from the plant should be useful for quality control procedures which are necessary for medicinal plants authentication protocols, such as monographs.

Author Contributions: J.P.-C., O.N.M.-C. and M.I.A.: designed the experiments; A.M., M.A.Á., C.S. and G.L.-I.: performed all the experiments; V.N.: antimicrobial activity; M.A.: botanical identification; B.R.-C. and G.L.-I.: experimental validation; M.I.A.: conceptualization, funding acquisition and wrote the paper and R.R.-G. made valuable revision.

Funding: This work was supported by the Consejo Nacional de Ciencia y Tecnología (CONACyT) grant number 271106 and by Dirección General de Asuntos del Personal Académico UNAM (DGAPA-PAPIIT, project IN222619).

Acknowledgments: To R. del-Carmen and R. Díaz for the technical assistance. To the technical staff of the USAII, particularly G. Duarte-Lisci, A. Acosta-Huerta, R.I. del Villar and M. Gutiérrez.

Conflicts of Interest: The authors declare no conflict of interest. 


\section{References}

1. Márquez, A.C.; Lara, F.; Esquivel, B.; Mata, R. Plantas Medicinales de México II. Composición, Usos Y Actividad Biológica; UNAM: Mexico City, Mexico, 1999; p. 165.

2. Favari-Perozzi, L.; Nava-Alvarez, R.; Meléndez-Camargo, M.E. Possible protective effect of verbena in rat liver injury induced by carbon tetrachloride. Rev. Mex. Cienc. Farm. 2007, 38, 19-25.

3. Osamu, S.; Hiroshi, H.; Homare, T.; Satoshi, Y.; Fuminobu, Y. A Skin Care Preparation and Skin Care Composition. Japanese Patent JP2002020232, 23 January 2002.

4. Castro, G.M.I.; Perez-Guil, R.F.; Madrigal, A.L. Chemical composition, toxic factors, and digestibility of Verbena carolina L. Turrialba 1991, 41, 289-292.

5. Deepak, M.; Handa, S. Quantitative Determination of the Major Constituents of Verbena officinalis using High Performance Thin Layer Chromatography and High Pressure Liquid Chromatography. Phytochem. Anal. 2000, 11, 351-355. [CrossRef]

6. Do Nascimento, P.G.G.; Lemos, T.L.G.; Bizerra, A.M.C.; Arriaga, A.M.V.; Ferreira, D.A.; Santiago, G.M.P.; Braz-Filho, R.; Costa, G.M. Antibacterial and antioxidant activities of ursolic acid and derivatives. Molecules 2014, 19, 1317-1327. [CrossRef]

7. Li, Y.; Matsunaga, K.; Kato, R.; Ohizumi, Y. Verbenachalcone, a novel dimeric dihydrochalcone with potentiating activity on nerve growth factor-action from Verbena littoralis. J. Nat. Prod. 2001, 64, 806-808. [CrossRef]

8. Mûller, A.; Ganzera, M.; Stuppner, H. Analysis of the aerial parts of Verbena officinalis L. by micellar electrokinetic capillary chromatography. Chromatographia 2004, 60, 193-197. [CrossRef]

9. Valento, P.; Andrade, P.; Areias, F.; Ferreres, F.; Seabra, R. Analysis of the vervain flavonoids by HPLC/Diod Array Detector Method. Its application to quality control. J. Agric. Food Chem. 1999, 47, 4579-4582. [CrossRef]

10. Chulasiri, M.; Bunyapraphatsara, N.; Moongkarndi, P. Mutagenicity and antimutagenicity of hispidulin and hortensin, the flavonoids from Millingtonia hortensis L. Environ. Mol. Mutagen. 1992, 20, 307-312. [CrossRef]

11. Gil, B.; Sanz, M.J.; Terencio, M.C.; Ferrandiz, M.L.; Bustos, G.; Paya, M.; Gunasegaran, R.; Alcaraz, M.J. Effects of flavonoids on Naja naja and human recombinant synovial phospholipases A2 and inflammatory responses in mice. Life Sci. 1994, 54, 333-338. [CrossRef]

12. Tan, R.X.; Lu, H.; Wolfender, J.L.; Yu, T.T.; Zheng, W.F.; Yang, L.; Gafner, S.; Hostettmann, K. Mono- and sesquiterpenes and antifungal constituents from Artemisia species. Planta Med. 1999, 65, 64-67. [CrossRef]

13. Kawadias, D.; Sand, P.; Youdim, K.A.; Qaiser, M.Z.; Rice-Evans, C.; Baur, R.; Sigel, E.; Rausch, W.D. The flavone hispidulin, a benzodiazepine receptor ligand with positive allosteric properties, traverses the blood-brain barrier and exhibits anticonvulsive effects. Br. J. Pharmacol. 2004, 142, 811-820.

14. Yuting, C.; Rongliang, Z.; Zhongjian, J.; Yong, Y. Flavonoids as superoxide scavengers and antioxidants. Free Radic. Biol. Med. 1990, 9, 19-21. [CrossRef]

15. Zhou, R.; Wang, Z.; Ma, C. Hispidulin exerts anti-osteoporotic activity in ovariectomized mice via activating AMPK signaling pathway. Cell Biochem. Biophys. 2014, 69, 311-317. [CrossRef]

16. He, L.; Lin, L.; Wang, J.; Wu, Y.; Chen, Y.; Yi, Z. Hispidulin, a small flavonoid molecule, suppresses the angiogenesis and growth of human pancreatic cancer by targeting vascular endothelial growth factor receptor 2-mediated PI3K/Akt/mTOR signaling pathway. Cancer 2011, 102, 219-225. [CrossRef]

17. Makino, Y.; Kondo, S.; Nishimura, Y.; Tsukamoto, Y.; Huang, Z.; Urade, Y. Hastatoside and verbenalin are sleep-promoting components in Verbena officinalis. Sleep Biol. Rhythms 2009, 7, 211. [CrossRef]

18. Singh, B.; Saxena, A.; Chandan, B.K.; Anand, K.K.; Suri, O.P. Hepatoprotective activity of verbenalin on experimental liver damage in rodents. Fitoterapia 1998, 69, 135-140.

19. Rimpler, H.; Schäfer, B. Hastatosid, ein neues Iridoid aus Verbena hastata L.und Verbena officinalis L. Z. Naturforschung 1979, 34c, 311-318. [CrossRef]

20. Scarpati, M.L. Isolamento dal Verbascum sinuatum di due nuovi glucosidi: Il verbascoside e l'isoverbascoside. Ann. Chim. 1963, 53, 356-367.

21. Andary, C.; Wylde, R.; Laffite, C.; Privat, G.; Winternitz, F. Structures of verbascoside and orobanchoside, caffeic acid sugar esters from Orobanche rapum-genistae. Phytochemistry 1982, 21, 1123-1127. [CrossRef]

22. Avila, J.G. Mode of action of Buddleja cordata verbascoside against Staphylococcus aureus. J. Ethnopharmacol. 1999, 66, 75-78. [CrossRef] 
23. Herbert, J.M.; Mafrand, J.P. Verbascoside isolated from Lantana camara, an inhibitor of protein kinase C. J. Nat. Prod. 1991, 54, 1595-1600. [CrossRef]

24. Speranza, L.; Franceschelli, S.; Pesce, M.; Reale, M.; Menghini, L.; Vinciguerra, I.; De Lutiis, M.A.; Felaco, M.; Grilli, A. Antiinflammatory effects in THP-1 cells treated with verbascoside. Phytother. Res. 2010, 24, 1398-1404. [CrossRef]

25. Chen, C.C.; Huang, H.Y.; Shen, C.C.; Huang, Y.L.; Ou, J.C. Chemical constituents of Verbena bonariensis. J. Chin. Pharm. Sci. 2003, 55, 65-70.

26. Arisawa, M.; Fukuta, M.; Shimizu, M.; Morita, N. The constituents of the leaves of Comanthosphace japonica S. Moore (Labiatae): Isolation of two new flavones glycosides, comanthosides A and B. Chem. Pharm. Bull. 1979, 27, 1252-1254. [CrossRef]

27. Murata, T.; Watahiki, M.; Tanaka, Y.; Miyase, T.; Yoshizaki, F. Hyaluronidase inhibitors from Takuran, Lycopus lucidus. Chem. Pharm. Bull. 2010, 58, 394-397. [CrossRef]

28. Ávila-Reyes, J.A.; Almaraz-Abarca, N.; Chaidez-Ayala, A.I.; Ramírez-Noya, D.; Delgado-Alvarado, E.A.; Torres-Ricario, R.; Naranjo-Jiménez, N.; Alanís-Bañuelos, R.E. Foliar phenolic compounds of ten wild species of Verbenacea as antioxidants and specific chemomarkers. Braz. J. Biol. 2018, 78, 98-107. [CrossRef]

29. ICH. Text on validation of Analytical Procedures. Harmonized tripartite guideline [Q2(R1)]. In Proceedings of the International Conference on Harmonization, Geneva, Switzerland, 1-13 November 2005; Available online: http://www.ich.org/fileadmin/public_Web_Site/ICH_Products/Guidelines/Quality/Q2_R1/Step4/Q2 R1_Guideline.pdf (accessed on 27 July 2012).

30. Habu, J.B.; Ibeh, B.O. In vitro antioxidant capacity and free radical scavenging evaluation of active metabolite constituents of Newbouldia laevis ethanolic leaf extract. Biol. Res. 2015, 48, 1-10. [CrossRef]

31. Okoh, S.O.; Asekun, O.T.; Familoni, O.B.; Afolayan, A.J. Antioxidant and Free Radical Scavenging Capacity of Seed and Shell Essential Oils Extracted from Abrus precatorius (L). Antioxidants 2014, 3, 278-287. [CrossRef]

32. Ríos, J.L.; Recio, M.C. Medicinal plants and antimicrobial activity. J. Ethnopharmacol. 2005, 100, 80-84. [CrossRef]

33. Navarro, V.; Villarreal, M.L.; Rojas, G.; Lozoya, X. Antimicrobial evaluation of some plants used in Mexican traditional medicine for the treatment of infectious deseases. J. Ethnopharmacol. 1996, 53, 143-147. [CrossRef]

34. Alvarez, L.; Pérez, M.C.; González, J.L.; Navarro, V.; Villarreal, M.L.; Olson, J.O. SC-1, an antimycotic spirostan saponin from Solanum chrysotrichum. Planta Med. 2001, 67, 372-374. [CrossRef]

35. Zamilpa, A.; Tortoriello, J.; Navarro, V.; Delgado, G.; Alvarez, L. Five new steroidal saponins from Solanum chrysotrichum leaves and their antimicrobial activity. J. Nat. Prod. 2002, 65, 1815-1819. [CrossRef] [PubMed]

36. Déciga-Campos, M.; Rivero-Cruz, I.; Arriaga-Alba, M.; Castañeda-Corral, G.; Angeles-López, G.E.; Navarrete, A.; Mata, R. Acute toxicity and mutagenic activity of Mexican plants used in traditional medicine. J. Ethnopharmacol. 2007, 110, 334-342. [CrossRef]

37. Cheng, Z.; Moore, J.; Yu, L. High-throughput relative DPPH radical scavenging capacity assay. J. Agric. Food Chem. 2006, 54, 7429-7436. [CrossRef] [PubMed]

38. Maldonado, P.D.; Rivero-Cruz, I.; Mata, R.; Pedraza-Chaverri, J. Antioxidant activity of a type proanthocyanidins from Geranium niveum (Geraniaceae). J. Agric. Food Chem. 2005, 53, 1996-2001. [CrossRef]

39. Benzie, I.F.F.; Strain, J.J. The ferric reducing ability of plasma (FRAP) as a measure of antioxidant power: The FRAP assay. Anal. Biochem. 1996, 239, 70-76. [CrossRef]

40. Ou, B.; Hampsch-Woodill, M.; Prior, R.L. Development and validation of an improved oxygen radical absorbance capacity assay using fluorescein as the fluorescent probe. J. Agric. Food Chem. 2001, 49, 4619-4626. [CrossRef]

41. Coballase-Urrutia, E.; Pedraza-Chaverri, J.; Carranza, R.; Cárdenas, N.; Huerta-Gertrudis, B.; Medina-Campos, O.N.; Mendoza-Cruz, M.; Delgado-Lamas, G.; Espinoza-Aguirre, J. Antioxidant activity of Heterotheca inuloides extracts and of some of its metabolites. Toxicology 2010, 276, 41-48. [CrossRef]

42. Blanco-Ayala, T.; Lugo-Huitrón, R.; Serrano-López, E.M.; Reyes-Chilpa, R.; Rangel-López, E.; Pineda, B.; Medina-Campos, O.N.; Sánchez-Chapul, L.; Pinzón, E.; Trejo-Solis, C.; et al. Antioxidant properties of xanthones from Calophyllum brasiliense: Prevention of oxidative damage induced by $\mathrm{FeSO}_{4}$. BMC Complement. Altern. Med. 2013, 13, 262. [CrossRef] 
43. Floriano-Sánchez, E.; Villanueva, C.; Medina-Campos, O.N.; Rocha, D.; Sánchez-González, D.J.; Cárdenas-Rodríguez, N.; Pedraza-Chaverri, J. Nordihydroguaiaretic acid is a potent in vitro scavenger of peroxynitrite, singlet oxygen, hydroxyl radical, superoxide anion and hypochlorous acid and prevents in vivo ozone-induced tyrosine nitration in lungs. Free Radic. Res. 2006, 40, 523-533. [CrossRef] [PubMed]

44. Rahalison, L.; Hamburger, M.; Monod, M.; Frenk, E.; Hostettmann, K. Antifungal test in phytochemical investigations: Comparison of bioautographic methods using phytopatogenic and human pathogenic fungi. Planta Med. 1994, 60, 41-44. [CrossRef]

45. Gadhi, C.; Benharref, A.; Jana, M.; Basile, A.; Contet-Audonneau, N.; Fortier, B. Antidermatophic properties of extracts from the leaves of Aristolochia paucinervis Pomel. Phytother. Res. 2001, 15, 79-81. [CrossRef]

46. Ríos, J.; Recio, M.; Villar, A. Screening methods for natural products with antimicrobial activity: A review of the literature. J. Ethnopharmacol. 1988, 23, 127-149. [CrossRef]

47. Lorke, D. A New Approach to Practical Acute Toxicity Testing. Arch. Toxicol. 1983, 54, 275-287. [CrossRef] [PubMed]

(C) 2019 by the authors. Licensee MDPI, Basel, Switzerland. This article is an open access article distributed under the terms and conditions of the Creative Commons Attribution (CC BY) license (http://creativecommons.org/licenses/by/4.0/). 